\title{
Modeling of water erosion by the erosion potential method in a pilot subbasin in southern Minas Gerais ${ }^{1}$
}

\section{Modelagem da erosão hídrica pelo método de erosão potencial em uma sub-bacia hidrográfica de referência no sul de Minas Gerais}

\author{
André Silva Tavares²; Velibor Spalevic ${ }^{3}$; Junior Cesar Avanzi ${ }^{4}$; Denismar Alves \\ Nogueira $^{5}$; Marx Leandro Naves Silva ${ }^{4}$; Ronaldo Luiz Mincato ${ }^{6 *}$
}

\begin{abstract}
Soil losses due to water erosion threaten the sustainability of agriculture and the food security of current and future generations. This study estimated potential soil losses and sediment production under different types of land uses in a subbasin in the Municipality of Alfenas, southern Minas Gerais, southeastern Brazil. The objective of this research was to evaluate the application of the Potential Erosion Method by the Intensity of Erosion and Drainage program and correlate the findings with the results obtained by the Revised Universal Soil Loss Equation as well as geoprocessing techniques and statistical analyses. In the Potential Erosion Method, the coefficient indicating the mean erosion intensity was 0.37 , which corresponded to erosion category IV and indicated weak laminar erosion processes, and the total soil loss was $649.31 \mathrm{Mg}$ year-1 and the mean was $1.46 \mathrm{Mg} \mathrm{ha}^{-1}$ year $^{-1}$. These results were consistent in magnitude with those obtained in the Revised Universal Soil Loss Equation, which estimated a mean soil loss of $1.52 \mathrm{Mg} \mathrm{ha}^{-1}$ year $^{-1}$ and a total soil loss of $668.26 \mathrm{Mg}_{\text {year }}{ }^{-1}$. The Potential Erosion Method suggests that $1.5 \%$ of the area presents potential soil losses above the soil loss tolerance limit, which ranged from 5.19 to $5.90 \mathrm{Mg} \mathrm{ha}^{-1}$ year $^{-1}$, while the Revised Universal Soil Loss Equation indicated that $7.3 \%$ of the area has potential soil losses above the limit. The maximum sediment discharge was 60 $\mathrm{Mg}$ year ${ }^{-1}$, meaning that $9.3 \%$ of the total soil loss reached the depositional areas of the river plains or watercourses. The Potential Erosion Method was efficient in the evaluation of water erosion in tropical soils, and the results were consistent with models widely employed in the estimation of soil losses. Thus, the model can support the evaluation of soil losses in Brazil and is a robust tool for evaluating the sustainability of agricultural activities.
\end{abstract}

Key words: Gavrilovic method. Hydrology. IntErO. Soil conservation.

1 Parte da Dissertação de Mestrado do primeiro autor.

2 Discente de Mestrado, Programa de Pós-Graduação em Ciências Ambientais, Universidade Federal de Alfenas, UNIFAL/MG, Alfenas, MG, Brasil. E-mail: andresttavares@gmail.com

3 Dr.Sc. in Agriculture, Department of Geography, University of Montenegro, Podgorica, Montenegro. E-mail: velibor.spalevic@, ac.me

4 Drs. em Ciência do Solo, Departamento de Ciência do Solo, Universidade Federal de Lavras, UFLA, Lavras, MG, Brasil. E-mail: junior.avanzi@ufla.br; marx@ufla.br

5 Dr. em Estatítica e Experimentação Agrícola, Instituto de Ciências Exatas, UNIFAL/MG, Alfenas, MG, Brasil. E-mail: denismar. nogueira@unifal-mg.edu.br

6 Dr. em Ciências, Instituto de Ciências da Natureza, UNIFAL-MG, Alfenas, MG, Brasil. E-mail: ronaldo.mincato@unifal-mg. edu.br

* Author for correspondence 


\section{Resumo}

Perdas de solo por erosão hídrica colocam em risco a sustentabilidade agrícola e a segurança alimentar das gerações atuais e futuras. Assim, este trabalho estimou as perdas potenciais de solo e a produção de sedimentos em diferentes tipos de usos da terra em uma sub-bacia hidrográfica no Município de Alfenas, sul de Minas Gerais, Sudeste do Brasil. A pesquisa teve como objetivo avaliar a aplicação do Método de Erosão Potencial pelo programa Intensidade de Erosão e Escoamento, correlacionando com os resultados obtidos pela Equação Universal de Perdas de Solo Revisada, aliado às técnicas de geoprocessamento e de análise estatística. No Método de Erosão Potencial, o coeficiente que indica a intensidade média da erosão foi de 0,37 , ou categoria IV de deterioração, que aponta processos de erosão laminar de grau fraco, com perda total de solo de $649,31 \mathrm{Mg}$ ano-1 e média de $1,46 \mathrm{Mg}^{-1} \mathrm{ha}^{-1}$ ano $^{-1}$. Os resultados corresponderam, em magnitude, aos obtidos na Equação Universal de Perdas de Solo Revisada, com perda média de solo de $1,52 \mathrm{Mg} \mathrm{ha}^{-1}$ ano $^{-1}$ e total de $668,26 \mathrm{Mg}$ ano ${ }^{-1}$. O Método de Erosão Potencial sugere que $1,5 \%$ da área possui perdas potenciais de solo acima do limite da Tolerância de Perda de Solo, que variou de 5,19 a 5,90 $\mathrm{Mg} \mathrm{ha}^{-1}$ ano $^{-1}$, enquanto a Equação Universal de Perdas de Solo Revisada indicou que 7,3\% da área possui perdas potenciais de solo acima do limite. A descarga máxima de sedimentos foi de $60 \mathrm{Mg}$ ano $^{-1}$, ou seja, 9,3\% da perda total de solo atinge as áreas deposicionais do deflúvio ou cursos d'água. O Método de Erosão Potencial mostrou eficiência na avaliação da erosão hídrica em solos tropicais, com resultados consistentes com modelos amplamente empregados na estimativa de perdas de solo, e dão suporte para a avaliação das perdas de solo no Brasil, sendo assim, uma ferramenta robusta para avaliar a sustentabilidade das atividades agrícolas.

Palavras-chave: Método de Gavrilovic. Hidrologia. IntErO. Conservação do Solo.

\section{Introduction}

Soil is an essential natural resource that supports terrestrial ecosystems and food production, which needs to increase as the population grows (FAO, 2015). However, soil takes thousands of years to form, and losses by water erosion are rapid and not compensated by soil formation rates (SCHULTZ et al., 2014). This scenario will lead to increased pressure on soils and deleterious effects on terrestrial ecosystems and agricultural production (DYONISIO, 2010). Thus, the adoption of conservation management is the best method of preserving this public good, although predatory uses intensify the natural processes and promote greater environmental degradation (SPERANDIO et al., 2012).

One of the obstacles to agricultural sustainability is water erosion (YOUSEFI et al., 2014), which occurs when the soil loss rates are higher than the formation rates (PANAGOS et al., 2015). The layer rich in nutrients and organic matter is removed at the beginning of the process, thereby changing the landscape dynamics and causing silting, flooding and water body contamination (MINELLA et al., 2011).

Brazil loses approximately 8 million tons per year of nitrogen, phosphorus and potassium fertilizers (FAO, 2015). Estimates reveal that 500 million tons of soil are annually eroded due to inadequate farming practices that remove vegetation and affect the water balance (BRADY; WEIL, 2013; SCHULTZ et al., 2014). Research on this topic is essential to evaluating the effectiveness of different soil conservation practices (OLIVEIRA et al., 2015).

Water erosion models are classified into empirical or regression models, conceptual models and physics-based models. Moreover, these models can be qualitative, quantitative and semiquantitative (DRAGICEVIC et al., 2016). De Vente and Poesen (2005) describe and compare semiquantitative models that use grouped variables to characterize a river basin. Most models lack data for validation because of the limited associated research, and 
they present application problems in large basins and limitations regarding their use under Brazilian edaphoclimatic conditions (SANTOS et al., 2013). In addition, these models include physical variables of river basins and thus depend on access to such data, which are still scarce and limit the application of more sophisticated models (SPALEVIC, 2011).

One of the semiquantitative empirical models for water erosion assessment that is widely used in Eastern Europe, the Middle East and North Africa is the Erosion Potential Method (EPM) (GAVRILOVIC, 1988). The EPM was developed from field experiments in the Morava basin (Serbia) and laboratory experiments that allowed creating tables of erosion factors (GAVRILOVIC, 1976). The EPM coefficients consist of soil resistance to water erosion, land use and management, observed erosion features, mean slope of the river basin, mean annual temperature and mean annual rainfall.

Due to the high amount of EPM input data, Spalevic (2011) developed the Intensity of Erosion and Outflow (IntErO) software, which can automatically calculate soil losses based on EPM coefficients and obtain results in a quick and accurate manner; moreover, it can avoid data errors resulting from manual processing (VUJACIC; SPALEVIC, 2016).

Other tools shown to be effective in soil loss estimates are based on geoprocessing techniques in a Geographic Information System (GIS) environment, and these tools contribute to assessing environmental degradation and defining the best practices for land use and management (EFTHIMIOU et al., 2016). Among the models better adapted to the application of geoprocessing techniques, the Revised Universal Soil Loss Equation (RUSLE) (RENARD et al., 1997) and the Universal Soil Loss Equation (USLE) (WISCHMEIER; SMITH, 1978) are the most used in Brazil (TERRANOVA et al., 2009). The EPM model with GIS spatially distributed input data was developed by Globevnik et al. (2003), among others. However, this model has been rarely applied in Brazil (SILVA et al., 2014).

One of the parameters used to evaluate the conservation conditions of agricultural lands is the Soil Loss Tolerance (SLT) (BERTOL; ALMEIDA, 2000), which indicates the maximum limit of acceptable soil loss to maintain the sustainability of agricultural production considering the different soil formation rates (CÂNDIDO et al., 2014).

Thus, this study aimed to estimate soil loss rates due to water erosion and evaluate the application of the EPM by correlating its results with the results obtained by RUSLE and SLT for a reference subbasin in the Alfenas Municipality, southern Minas Gerais State, southeastern Brazil.

\section{Materials and Methods}

\section{Study Area}

The study area is the Córrego da Laje River Subbasin, which is a tributary of the Furnas Hydroelectric Power Plant reservoir and located at the Capoeirinha Farm (Ipanema Agrícola S.A.) in Alfenas, Minas Gerais State (MG), Brazil, at UTM 23K 402000 to $405000 \mathrm{~m} \mathrm{E}$ and 7616700 to 7620200 m N, Datum SIRGAS 2000.

According to the EPM model, the physical parameters of the study area are as follows: subbasin area (F) of 437 ha, perimeter (O) of 9.90 $\mathrm{km}$, minimum altitude $\left(\mathrm{H}_{\text {min }}\right)$ of $814 \mathrm{~m}$, maximum altitude $\left(\mathrm{H}_{\max }\right)$ of $914 \mathrm{~m}$, length of the main stream $\left(\mathrm{L}_{\mathrm{v}}\right)$ of $2.98 \mathrm{~km}$ and shortest distance between the source and mouth $\left(\mathrm{L}_{\mathrm{m}}\right)$ of $2.15 \mathrm{~km}$. The Köppen classification of the climate is Tropical Mesothermic (CwB) (SPAROVEK et al., 2007). The relief belongs to the 'mares de morros' (seas of hills) physiographic unit, which is in the southern plateau of MG in the Varginha-Guaxupé Complex (UFRJ; CPRM, 2010). The geological substrate of the subbasin consists of garnet-biotite gneisses and biotite gneisses. 
The digital soil map was based on topographic variation as a soil formation element (MCBRATNEY et al., 2003), and it included morphological descriptions and physical and chemical laboratory analyses. For this purpose, a digital elevation model (DEM) was obtained (Figure 1A) via the interpolation of contours at 20- to $10-\mathrm{m}$ resolution (pixel) based on the Alfenas Topographic Map (IBGE, 1970) using the Topo to Raster tool in ArcGIS 10.3 software (ESRI, 2015). The relief classes (IBGE, 2015) were obtained from the slope map (Figure 1B) using the ArcGIS 10.3 Slope tool.

Figure 1. Digital elevation map (A) and slope map (B) of the Córrego da Laje River Subbasin in Alfenas, southern Minas Gerais, Brazil.

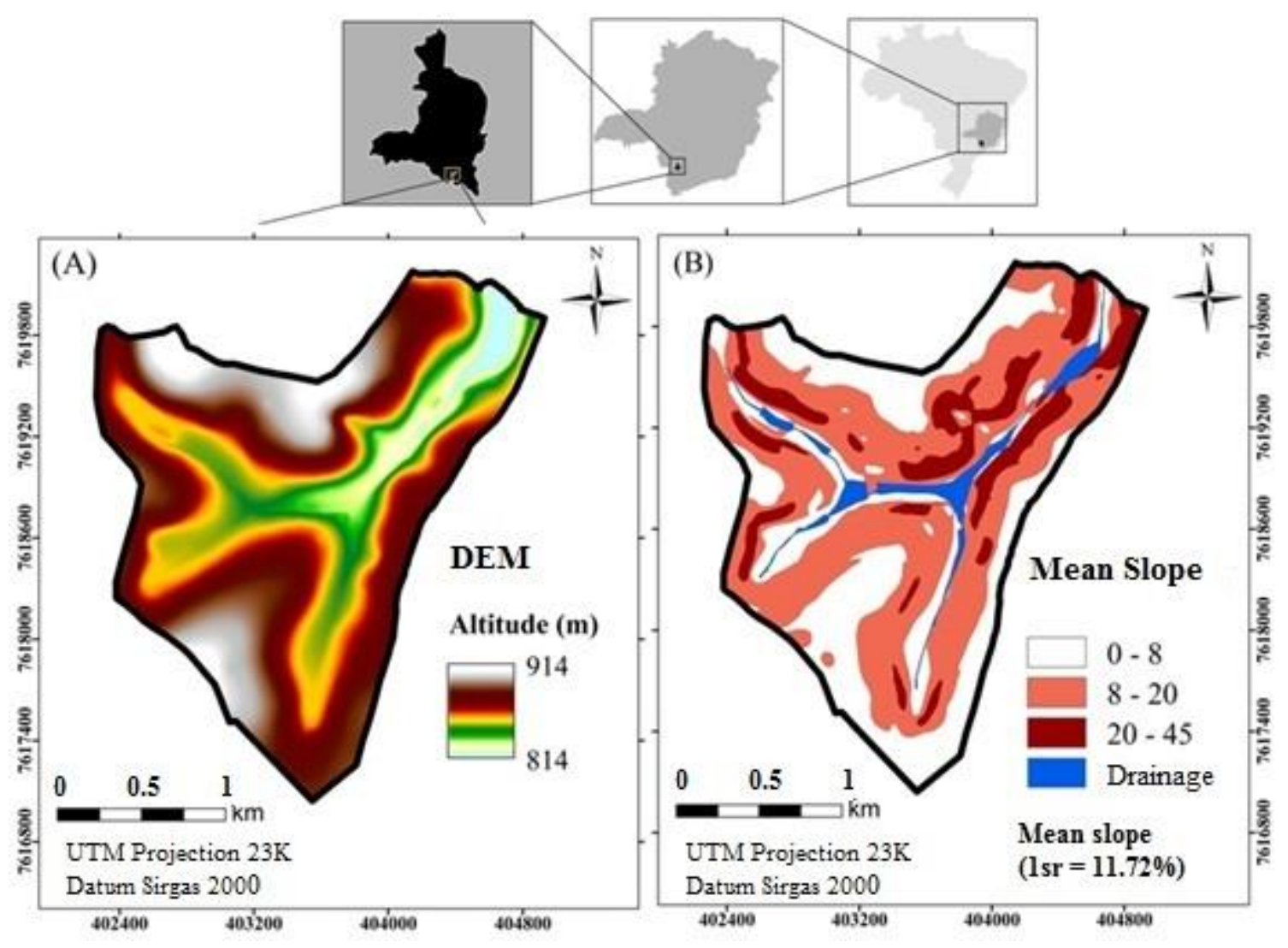

Soil samples were collected in March and April 2016 according to Santos et al. (2015). Disturbed samples, undisturbed cylinder samples $\left(92.53 \mathrm{~cm}^{3}\right)$ and undisturbed chunk samples were obtained at depths of $0-20$ and $20-60 \mathrm{~cm}$ for each of the three relief classes under native forest and under coffee crops. The morphological description of the physical attributes was conducted in micro trenches measuring $40 \times 40 \times 60 \mathrm{~cm}$ in the eighteen sampled sites.
The following laboratory analyses were performed: particle size distribution (texture), which was analyzed by the pipette method with and without addition of $\mathrm{NaOH} 1 \mathrm{~mol} \mathrm{~L}^{-1}$ (BLACK, 1986); bulk density, which was analyzed by the volumetric ring method (BLAKE; HARTGE, 1986); total porosity (DANIELSON; SUTHERLAND, 1986); microporosity, which was analyzed by the tension table method with suction equivalent to a $60-\mathrm{cm}$ high water column; macroporosity, which was 
analyzed by the difference between total porosity and microporosity (GROHMANN, 1960); and organic matter, which was analyzed by calorimetry of the oxidation of $\mathrm{Na}_{2} \mathrm{Cr}_{2} \mathrm{O}_{7} 1 \mathrm{~mol} \mathrm{~L}^{-1}$ and $\mathrm{H}_{2} \mathrm{SO}_{4} 5 \mathrm{~mol} \mathrm{~L}^{-1}$.

Soil permeability was obtained in the field with a Decagon Devices Mini Disk Infiltrometer with a suction rate of $2 \mathrm{~cm}$ (ZHANG, 1997). Three replicates were used for each of the eighteen sampled sites. The permeability classification considered the soil texture and structure (SSDS, 1993; GALINDO; MARGOLIS, 1989), and the soil classification was according to the Brazilian Agricultural Research Corporation (EMBRAPA, 2013). The land use map was generated from Landsat-8 Thematic Mapper (TM) satellite images, in the bands TM6, TM5 and
TM4 (orbit/point 219/75) obtained from the United States Geological Survey (USGS) and field checks. The images were processed using ArcGIS 10.3 (ESRI, 2015).

Coefficients for the calculation of soil losses in the Potential Erosion Method

The coefficients for calculating soil losses in the EPM (Table 1, Equation I) include the mean annual rainfall, mean temperature (Table 1, Equation II) and erosion intensity (Table 1, Equation III), and sediments retained in the terrain and those that contribute to runoff were quantified (Table 1, Equation IV).

Table 1. Equations and descriptions of the input parameters for estimating soil losses in the EPM model.

$$
\begin{gathered}
\mathbf{G}_{\mathbf{y r}}=\mathbf{T} \cdot \mathbf{H}_{\mathbf{y r}} \cdot \pi \cdot \sqrt[2]{\mathbf{Z}^{3}} \cdot \mathbf{R}_{\mathbf{u}} \\
T=\sqrt[2]{\frac{\mathbf{t}_{\mathbf{0}}}{10}}+0,1
\end{gathered}
$$

$\mathrm{G}_{\mathrm{yr}}=$ mean soil loss $\left(\mathrm{m}^{3} \mathrm{~km}^{-2}\right.$ year $\left.^{-1}\right)$

$\mathrm{T}=$ temperature coefficient $\left(\operatorname{Dim}^{(*)}\right)$

$\mathrm{H}_{\mathrm{yr}}=$ mean precipitation $\left(\mathrm{mm}\right.$ year $\left.^{-1}\right)$

$\mathrm{Z}=$ erosion coefficient (Dim)

$\mathrm{R}_{\mathrm{u}}=$ sediment retention coefficient (Dim).

$\mathrm{t}_{0}=$ mean air temperature $\left({ }^{\circ} \mathrm{C}\right.$ year $\left.{ }^{-1}\right)$

$\mathrm{Y}=$ soil resistance to water erosion $(\mathrm{Dim})$

$\mathrm{X}_{\mathrm{a}}=$ land use and management (Dim)

$\varphi=$ erosion observed in the field (Dim)

$\mathrm{I}_{\mathrm{sr}}=$ mean slope $(\%)$

$\mathrm{O}=$ length of the subbasin $(\mathrm{km})$

$\mathrm{D}=$ slope length $(\mathrm{m})$

$\mathrm{Lv}=$ length of the main stream $(\mathrm{km})$

$\operatorname{Dim}^{(*)}$ : Dimensionless. Source: Gavrilovic (1988) and De Vente and Poesen (2005).

Soil resistance to water erosion (Y) differs according to the soil attributes (PANAGOS et al., 2015). Gavrilovic (1988) defined soil resistance to particle disaggregation and removal values based on between 0.25 and 2.00, and the values were primarily dependent on the characteristics of the source material and the rocky substrate (TANGESTANI, 2006).

The geological framework of the area is formed by garnet-biotite gneisses and biotite gneisses, and under the conditions of soil development, these substrates tend to form thick well-developed soils rich in kaolinitic clays with a low propensity to natural erosion.

The land use and management coefficient $\left(\mathrm{X}_{\mathrm{a}}\right)$ is lower in areas with good soil conservation and vegetation cover practices, especially in agricultural areas (ZORN; KOMAC, 2009). In the studied area, the values defined for the land use and management classes were as follows: native forest, 0.05 ; corn 
and bean crops in succession with no-till, 0.40; coffee cultivated under a contour farming system, 0.70; eucalyptus with "downhill" planting, 0.90; and access routes with exposed soil, 1.00.

The field erosion coefficient $(\varphi)$ represents the occurrence of erosion features associated with the land uses. Values range between 0.01 for areas with weak laminar erosion and 1.00 for advanced laminar erosion and severe linear erosion features, such as ravines and gullies. In the area, the values were defined according to the presence of erosion features with each land use and by considering the vegetation cover and soil management: native forest, 0.10; corn and bean crops in succession, 0.30 ; coffee, 0.50; eucalyptus, 0.60; and access routes, 0.70 (Table 2 ).

In addition to soil losses, the EPM estimates the amount of sediment that reaches the depositional areas in the water basin runoff (Table 3 ). The mean water level $\left(h_{b}\right)$ was obtained from the annual mean of heavy rainfall (above $70 \mathrm{~mm}$ ) and 24-hour duration between 1981 and 2014 from the annual data of three rainfall stations in the municipalities of Alfenas, Machado and Paraguaçu, MG (ANA, 2016).

Table 2. Mean values for the land use and management $\left(\mathrm{X}_{\mathrm{a}}\right)$, observed erosion $(\varphi)$ and soil resistance $(\mathrm{Y})$ coefficients.

\begin{tabular}{|c|c|c|c|c|c|c|c|}
\hline \multicolumn{2}{|c|}{ Area } & \multicolumn{3}{|c|}{$X_{a}$} & \multicolumn{2}{|l|}{$\varphi$} & \multirow{2}{*}{$\frac{\mathrm{Y}}{0.25-2.00}$} \\
\hline (ha) & $(\%)$ & Land Use and Management & $0.05-1.0$ & Erosion & $0.1-1.0$ & Soils & \\
\hline 68.99 & 15.78 & Native Forest & 0.05 & Very Weak & 0.10 & $\operatorname{LVd}^{(*)}$ & 0.90 \\
\hline 60.49 & 13.84 & Corn/Beans & 0.40 & Weak & 0.30 & LVd1 & 0.90 \\
\hline 237.3 & 54.31 & Coffee & 0.70 & Moderate & 0.50 & $\operatorname{LVd} 2^{(*)}$ & 0.90 \\
\hline 16.95 & 3.88 & Eucalyptus & 0.90 & Moderate & 0.60 & $\mathrm{LVd} 2$ & 0.90 \\
\hline 9.71 & 2.22 & Access Routes & 1.00 & Strong & 0.70 & $\mathrm{LVd}^{(*)}$ & 0.90 \\
\hline 21.60 & 4.95 & Deposition Area & 0.00 & - & 0.00 & LVd1 & 0.00 \\
\hline 2.40 & 0.55 & Fertilizer Shed & 0.00 & - & 0.00 & $\mathrm{LVd} 2$ & 0.00 \\
\hline 19.51 & 4.47 & Drainage & 0.00 & - & 0.00 & $\mathrm{LVd} 2$ & 0.00 \\
\hline 437 & 100 & & 0.50 & & 0.37 & & 0.90 \\
\hline
\end{tabular}

$\operatorname{LVd1}^{(*)}$ : Dystrophic Red Latosol in a flat to gently undulating relief; LVd2 ${ }^{(*)}$ : Dystrophic Red Latosol in an undulating relief; $\mathrm{LVd}^{(*)}$ : Dystrophic Red Latosol in a strongly undulating relief.

The physical characteristics of the subbasin, such as shape, symmetry, sinuosity, channel development, drainage density, width, length and perimeter, were obtained using GIS by geoprocessing according to the specialized literature (OLSZEVSKI et al., 2011; VILLELA; MATTOS, 1975). 
Table 3. Equations and descriptions of input parameters for the calculation of the maximum flow rate $\left(\mathrm{Q}_{\max }\right)$.

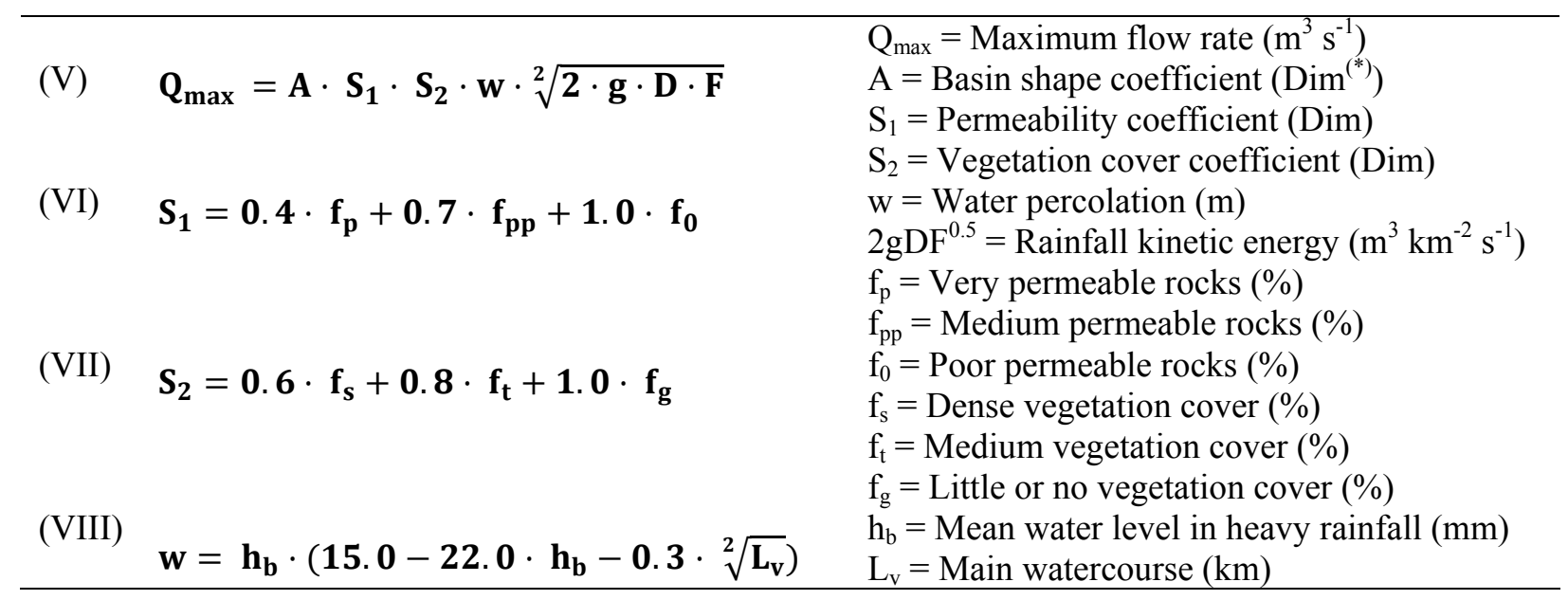

$\operatorname{Dim}^{(*)}$ : Dimensionless. Source: Gavrilovic (1988).

The soil losses were determined by the EPM using IntErO software (SPALEVIC, 2011), the distribution of soil losses was determined using GIS in ArcGIS 10.3 (ESRI, 2015), and the raster calculator tool was used to generate the final map of soil losses.

\section{RUSLE Model Parameters}

The RUSLEmodel equation works by multiplying the following factors: $\mathrm{R}$, or rainfall erosivity (MJ $\mathrm{mm} \mathrm{ha}^{-1} \mathrm{~h}^{-1}$ year $\left.{ }^{-1}\right)$; , or soil erodibility $\left(\mathrm{Mg} \mathrm{h} \mathrm{MJ}^{-1}\right.$ $\mathrm{mm}^{-1}$ ); LS, or topographic (dimensionless); C, or soil cover (dimensionless); and $\mathrm{P}$, or conservation practices (dimensionless).

The $\mathrm{R}$ factor $\left(6,500 \mathrm{MJ} \mathrm{mm} \mathrm{ha}^{-1} \mathrm{~h}^{-1}\right.$ year $\left.{ }^{-1}\right)$ was determined for southern MG by Aquino et al. (2012) based on the Fournier equation with the kriging interpolation method adjusted for Lavras, MG and is used in studies in the region (AYER et al., 2015; OLIVETTI et al., 2015). The C and P values were obtained from Bertol et al. (2001) for no-till corn/beans $(\mathrm{C}=0.0271 ; \mathrm{P}=0.01)$, Prochnow et al. (2005) for coffee with a spacing of $3.0 \times 0.5$ $\mathrm{m}$ under a contour farming system $(\mathrm{C}=0.1354$; $\mathrm{P}$
$=0.50)$ and Silva et al. (2016) for eucalyptus under downhill planting system $(\mathrm{C}=0.1240 ; \mathrm{P}=1.00)$ and preserved native forest $(\mathrm{C}=0.0150 ; \mathrm{P}=0.01)$.

The K and LS factors were calculated for the soils of the Corrego da Laje River subbasin. The $\mathrm{K}$ factor was obtained by calculating the indirect estimate in Latosols (SILVA et al., 1999) and the LS from the DEM and geoprocessing techniques, thereby obtaining the contribution area, direction flow and runoff accumulation flow (MITASOVA et al., 2001; OLIVEIRA et al., 2013).

\section{Soil Attributes for the Calculation of Soil Loss Tolerance}

The most used method in Brazil for calculating the SLT is the one developed by Bertol and Almeida (2000), which uses the largest number of soil attributes in its formulation (CÂNDIDO et al., 2014). The method multiplies the following attributes: $\mathrm{h}=$ effective soil depth (mm), which is limited to 1,000 $\mathrm{mm}$; ra = ratio that jointly expresses the effect of the textural relationship between horizons $\mathrm{B}$ and $\mathrm{A}$ and the clay content of horizon $\mathrm{A} ; \mathrm{m}=$ factor expressing the effect of organic matter on the $0-20 \mathrm{~cm}$ soil 
layer; $\mathrm{p}=$ factor expressing the effect of the soil permeability; and $1,000^{-1}=$ constant expressing the time required to erode a $1,000 \mathrm{~mm}$ thick soil layer.

To evaluate the goodness of fit of the EPM model, approximately five thousand randomly extracted points (pixels) with a minimum distance of $10 \mathrm{~m}$ were correlated using the 'create random points' and 'extract value to point' tools in ArcGIS 10.3 software and based on the soil loss maps obtained with the RUSLE and EPM models. The points were grouped considering the variables 'land use' and 'slope'. The data were statistically analyzed using Spearman's correlation coefficient with 5\% significance in the Statistical Package for Social Sciences (SPSS-IBM, 2017).

\section{Results and Discussion}

In the studied subbasin, the mean rainfall $\left(\mathrm{H}_{\mathrm{yr}}\right)$ was 1,500 mm year-1 (SPAROVEK et al., 2007), the mean water level in heavy rains $\left(\mathrm{h}_{\mathrm{b}}\right)$ was 82.50 $\mathrm{mm}$ and the rainfall kinetic energy $\left(2 \mathrm{gDF}^{0.5}\right)$ was $56.37 \mathrm{~m}^{3} \mathrm{~km}^{-2} \mathrm{~s}^{-1}$. The mean air temperature $\left(\mathrm{t}_{0}\right)$ was $22^{\circ} \mathrm{C}$ (INMET, 2016) and the temperature coefficient (T) was 1.52 . The length of the class 1 and 2 watercourses $\left(\Sigma_{\mathrm{L}}\right)$ was $5.97 \mathrm{~km}$, resulting in a drainage density $(\mathrm{G})$ of $1.25 \mathrm{~km} \mathrm{~km}^{-2}$, indicating high drainage flow to the subbasin. The sinuosity index $(\mathrm{K})$ was 1.09 , which indicates low sinuosity in the hydrological dynamics. The shape of the subbasin (A), calculated as 0.65 , indicates little tendency to flooding in the area. The mean width of the subbasin (B) was $3.40 \mathrm{~km}$.

The subbasin appears very asymmetric $(a=0.02)$ and the difference in elevation, which represents the mean slope length (D) in the runoff, was $37.21 \mathrm{~m}$. The mean altitude of the subbasin $\left(\mathrm{H}_{\mathrm{leb}}\right)$, which leads to variations in temperatures and evapotranspiration, was $847.21 \mathrm{~m}$, and the mean height of the terrain erosion was $104 \mathrm{~m}$. The development coefficient of the subbasin $(\mathrm{m})$ obtained was 0.40 . The volume of percolated water in the subsurface layer (w) was $1.05 \mathrm{~m}$, with a maximum flow rate $\left(\mathrm{Q}_{\max }\right)$ of 29.65 $\mathrm{m}^{3} \mathrm{~s}^{-1}$.

The subbasin relief classes are as follows: flat to gently undulating $(0-8 \%)$, undulating (8-20\%) and strongly undulating (20-45\%) (Figure 1B). The mean slope $\left(\mathrm{I}_{\mathrm{sr}}\right)$ was $11.72 \%$.

The soils were classified as dystrophic red latosol in flat to smooth gently undulating relief (LVd1), undulating relief (LVd2), strongly undulating relief (LVd3) and indiscriminate floodplain soils (IFS), which covered $26.77 \%, 46.60 \%, 14.30 \%$ and $9.40 \%$ of the area, respectively (Figure 2A). The IFS loss was not calculated because the studied area is a deposition area.

The soil resistance to water erosion (Y) for the soil classes was 0.90, which indicates good resistance (GAVRILOVIC, 1988) because of the physical characteristics of the soil and rocky substrate. The soil structure was classified as medium subangular blocky in soil classes LVd1 and LVd2, weak subangular blocky in LVd3, slightly plastic consistency in LVd1 and LVd2 and plastic in $\mathrm{LVd} 3$. The clay contents ranged from 58.40 to $60.70 \%$, and the texture was defined as clayey to very clayey. The mean bulk density was $1.15 \mathrm{Mg}$ $\mathrm{m}^{-3}$, and large variations were not observed with depth, which favors permeability (ARSHAD et al., 1996). The permeability $\left(S_{1}\right)$ was considered low (SSDS, 1993; GALINDO; MARGOLIS, 1989) at a value of 1.00 , which was due to the clayey to very clayey texture and subangular blocky structure. The high metamorphic degree of the biotite gneiss and garnet-biotite gneiss lithotypes indicate a rocky substrate with medium permeability.

The $\mathrm{K}$ factor of the RUSLE model was 0.021 , 0.004 and $0.026 \mathrm{Mg} \mathrm{h} \mathrm{MJ}^{-1} \mathrm{~mm}^{-1}$ for soil classes $\mathrm{LVd} 1, \mathrm{LVd} 2$ and $\mathrm{LVd} 3$, respectively. The mean value of the LS factor was 0.318 . 
Figure 2. Digital soil map (A) and land use map (B) of the Córrego da Laje River Subbasin, southern Minas Gerais, Brazil. Notes: Dystrophic Red Latosol in flat and gently undulating (LVd1), undulating (LVd2) and strongly undulating (LVd3) reliefs. Indiscriminate floodplain soils (IFS).

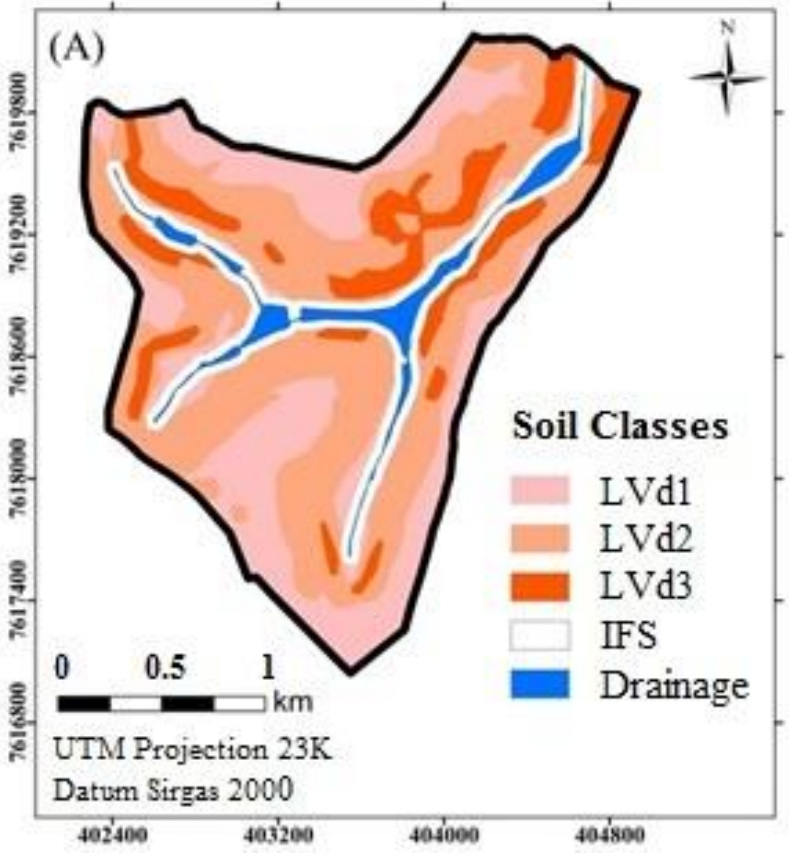

The mean land use and management coefficient $\left(\mathrm{X}_{\mathrm{a}}\right)$ in the EPM had a value of 0.50 , which indicates good land use management due to the use of conservation practices, namely, contour and notill farming systems, in approximately $70 \%$ of the area. The vegetation cover coefficient $\left(\mathrm{S}_{2}\right)$ was 0.78 , which indicates good soil protection.

The mean erosion value observed in the terrain $(\varphi)$ was 0.37 , which indicates the predominance of weak laminar erosion and different levels of erosion intensity according to soil conditions, permeability, slope, land use and management. According to the EPM, the degree of erosion in forest areas (15.78\%) was intensive; therefore, a value of 0.10 was assigned to it. However, in areas with exposed soils $(2.22 \%)$, a value of 0.70 was assigned. The erosion coefficient $(Z)$ ranged from

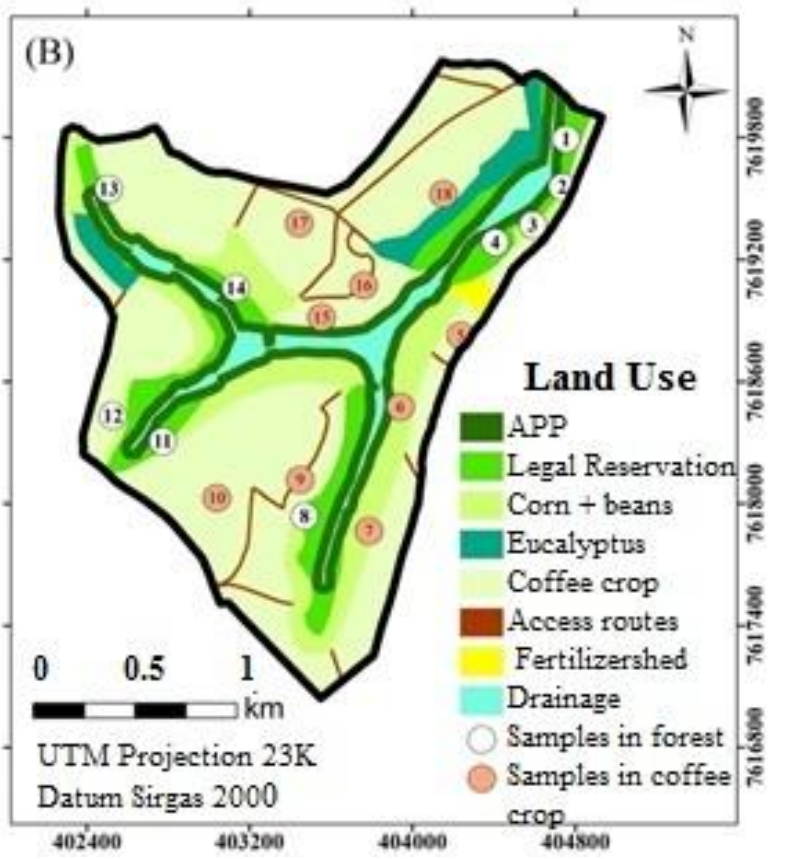

0.01 to 1.12 , with a mean of 0.37 , which indicates the predominance of erosion category IV, which is of weak intensity (Figure 3A). The preserved native forest areas showed erosion rates between 0.01 and 0.03 , or category $\mathrm{V}$, which is of very weak intensity and contributes $1.05 \%$ to the erosion intensity.

Access routes with exposed soils indicated the highest mean erosion intensity at 0.81 , and the maximum was 1.12 . These areas belong to erosion category II, which is of intensive erosion. These values are associated with the high slope of the land and poor vegetation cover. Although it occupies the smallest area among the land uses, the access routes contribute the most to the erosion intensity at $38.75 \%$, thus revealing the lack of soil conservation practices in these sites (Table 4). 
Table 4. Erosion intensity values $(Z)$ in each land use class.

\begin{tabular}{cccccccc}
\hline $\begin{array}{c}\text { Land Use Classes } \\
\text { of the Soil }\end{array}$ & \multicolumn{2}{c}{ Area } & $\begin{array}{c}\text { Mean } \\
(\mathrm{Z})\end{array}$ & $\begin{array}{c}\text { Maximum } \\
(\mathrm{Z})\end{array}$ & $\begin{array}{c}\text { Category } \\
(\mathrm{Z})\end{array}$ & Z & $\begin{array}{c}\text { Contribution } \\
(\mathrm{Z})\end{array}$ \\
\hline ha & $\%$ & & & I - V & & $\%$ \\
\hline Coffee & 237.3 & 54.31 & 0.42 & 0.70 & IV & Weak & 24.22 \\
Corn + Beans & 60.49 & 13.84 & 0.17 & 0.25 & V & Very Weak & 8.65 \\
Eucalyptus & 16.95 & 3.88 & 0.63 & 0.79 & III & Moderate & 27.33 \\
Native Forest & 68.99 & 15.78 & 0.01 & 0.03 & V & Very Weak & 1.05 \\
Access Routes & 9.71 & 2.22 & 0.81 & 1.00 & II & Strong & 38.75 \\
Fertilizer Shed & 2.40 & 0.55 & - & - & - & - & - \\
Drainage & 19.51 & 4.47 & - & - & - & - & - \\
Deposition Area & 21.60 & 4.95 & - & - & - & - & - \\
\hline Total & 437 & 100 & 0.37 & $0.01-1.00$ & II to V & & 100 \\
\hline
\end{tabular}

The soil loss map of the EPM model was classified according to Beskow et al. (2009) (Figure $3 \mathrm{~B})$. In the coffee crops under contour farming (54.78\%), the soil losses ranged from 1.53 to 4.41 $\mathrm{Mg} \mathrm{ha}^{-1}$ year' ${ }^{-1}$, with a mean of $2.09 \mathrm{Mg} \mathrm{ha}^{-1}$ year $^{-1}$.

The SLT values were 5.19, 5.69 and 5.90 $\mathrm{Mg} \mathrm{ha}^{-1}$ year $^{-1}$, respectively, for the $\mathrm{LVd} 1, \mathrm{LVd} 2$ and $\mathrm{LVd} 3$ soils. The result of the variable h was $1,000 \mathrm{~mm}$, the weighting value of the variable ra was 1 , and the weighting of the variables $\mathrm{m}$ and $\mathrm{p}$ was 0.7 .
The lowest soil loss rates were associated with preserved native forest areas $(15.78 \%)$, which had values between 0.002 and $0.40 \mathrm{Mg} \mathrm{ha}^{-1}$ year $^{-1}$ and a mean of $0.009 \mathrm{Mg} \mathrm{ha}^{-1}$ year $^{-1}$, and no-till corn and beans in succession (13.84\%), which had values between 0.31 and $0.93 \mathrm{Mg} \mathrm{ha}^{-1}$ year $^{-1}$ and a mean of $0.55 \mathrm{Mg} \mathrm{ha}^{-1}$ year $^{-1}$. These results demonstrate the efficiency of conservation management practices and the presence of native vegetation cover on the margins of the water resources.

Figure 3. Map of erosion intensity (Z) (A) and spatial distribution map of soil losses (B) according to the classification of Beskow et al. (2009) in the Corrego da Laje River Subbasin, southern Minas Gerais, Brazil. (DA) Deposition Area; (FS) Fertilizer shed.
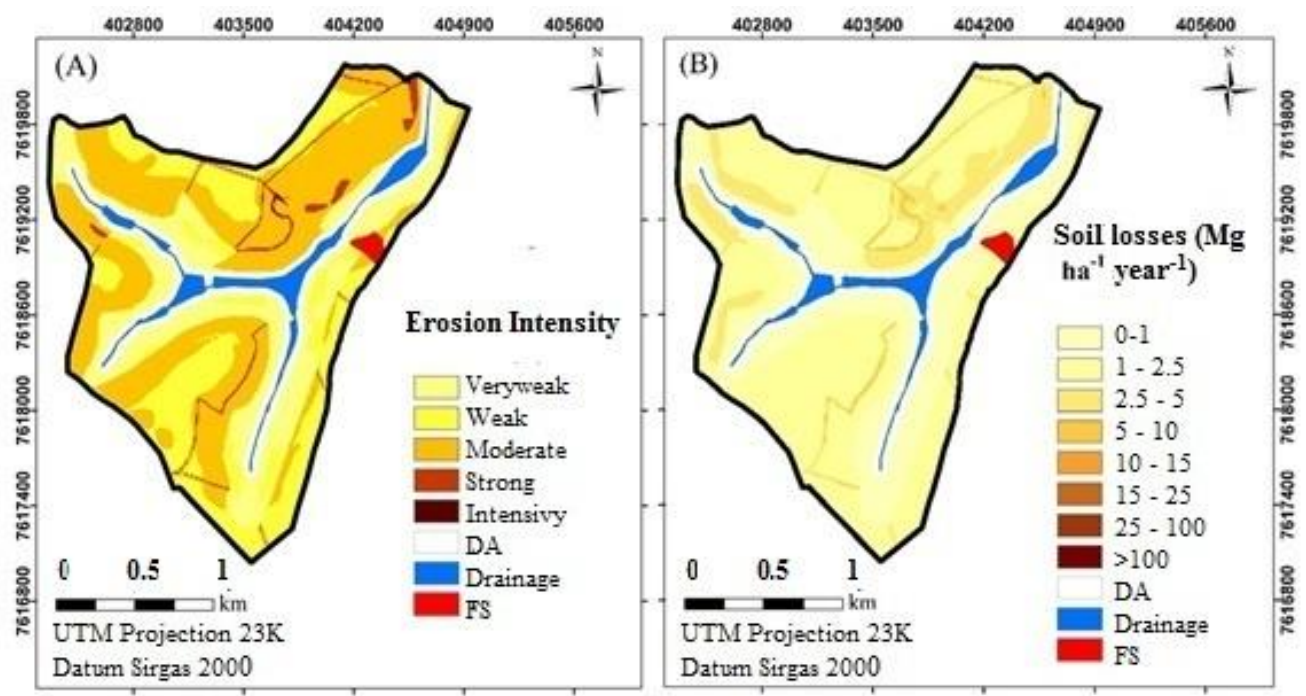
The eucalyptus planting was characterized as downhill planting, which is a management type that does not respect the topographic contour lines (PRUSKI, 2009), and the soil losses ranged

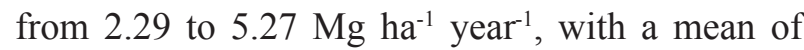
$3.77 \mathrm{Mg} \mathrm{ha} \mathrm{h}^{-1}$ year $^{-1}$, which is above the average of the subbasin due to the absence of conservation practices but below the minimum SLT limit. Access routes $(2.22 \%)$ showed the highest soil loss rates at between 4.39 and $8.87 \mathrm{Mg} \mathrm{ha}^{-1}$ year $^{-1}$ and mean of $5.50 \mathrm{Mg} \mathrm{ha}^{-1}$ year $^{-1}$. Such values may be associated with the lack of vegetation cover, the slope of the terrain and the heavy traffic of large vehicles (harvesters), which reduce the macroporosity of the soil and increase surface runoff.

The area of the fertilizer shed $(0.55 \%)$ is waterproofed, and the areas of drainage, floodplains and sediment deposition $(9.42 \%)$ were not subject to the soil losses calculation.

The EPM indicated that only $1.5 \%$ of the subbasin had soil losses above the SLT limit. The RUSLE model estimated soil losses at $7.35 \%$ above the limit. The mean soil loss according to the EPM

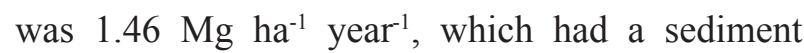
retention coefficient $\left(\mathrm{R}_{\mathrm{u}}\right)$ of 0.093 , indicating that
$9.3 \%$ or $60.37 \mathrm{Mg}$ year $^{-1}$ of sediments reach the runoff areas and $90.7 \%$ or $588.94 \mathrm{Mg} \mathrm{year}^{-1}$ are retained in terrain depressions. The total soil loss calculated by the EPM was $649.31 \mathrm{Mg}$ year-1 $^{-1}$ In the RUSLE model, the mean soil loss rate was 1.52 $\mathrm{Mg} \mathrm{ha}^{-1}$ year- $^{-1}$ and the total loss was $668.2 \mathrm{Mg}$ year $^{-1}$ (Table 5).

The EPM model in the IntErO software presents tabulated input and output data at the end of the automated modeling process (Table 6).

In the coffee crops, 1,877 soil loss points were statistically assessed in the different slope classes (Figure 4A), and they did not show a good correlation with the slope variation $(r=0.006 ; p>$ $0.05)$; however, a significant correlation $(r=0.15 ; \mathrm{p}$ $<0.001$ ) was observed between the values obtained by the EPM and by the RUSLE. Such results can be explained by the land use and management, which had corresponding values in the two models despite the differences in the order of magnitude obtained by the two models. Soil losses as a function of the slope are associated with the soil resistance to erosion (Y) and erodibility $(\mathrm{K})$, which did not show significant variations in the EPM $(\mathrm{Y}=0.90)$ and RUSLE ( $K=0.021$ to 0.026$)$.

Table 5. Soil losses based on the EPM and RUSLE for different land use classes.

\begin{tabular}{lccccccc}
\hline \multirow{2}{*}{ Land Use } & Area & \multicolumn{2}{c}{ Mean soil loss soil } & \multicolumn{2}{c}{ Total loss soil } & \multicolumn{2}{c}{${ }^{(*} \mathrm{R}_{\mathrm{u}}=0.093$} \\
\cline { 2 - 8 } & \multirow{2}{*}{ ha } & \multicolumn{2}{c}{ Mg ha $^{-1}$ year $^{-1}$} & \multicolumn{2}{c}{ Mg year } & \multicolumn{2}{c}{ Mg year ${ }^{-1}$} \\
\cline { 2 - 8 } & & EPM & RUSLE & EPM & RUSLE & EPM & RUSLE \\
\hline Coffee & 237.35 & 2.090 & 1.58 & 497.85 & 375.01 & 46.30 & 34.87 \\
Corn + Beans & 60.49 & 0.100 & 0.12 & 33.42 & 7.26 & 3.10 & 0.67 \\
Eucalyptus & 16.95 & 3.770 & 6.08 & 63.98 & 103.05 & 5.95 & 9.58 \\
Native Forest & 68.99 & 0.009 & 0.01 & 0.60 & 0.69 & 0.06 & 0.06 \\
Access Routes & 9.71 & 5.500 & 18.77 & 53.46 & 182.25 & 4.97 & 16.94 \\
Fertilizer Shed & 2.40 & - & - & - & - & - & - \\
Drainage & 19.51 & - & - & - & - & - & - \\
Deposition Area & 21.60 & - & - & - & - & - & - \\
\hline \multicolumn{1}{c}{ Total } & 437.00 & 1.460 & 1.52 & 649.3 & 668.2 & 60.37 & 62.14 \\
\hline
\end{tabular}

${ }^{(*)} \mathrm{R}_{\mathrm{u}}=$ Sediment retention coefficient. 


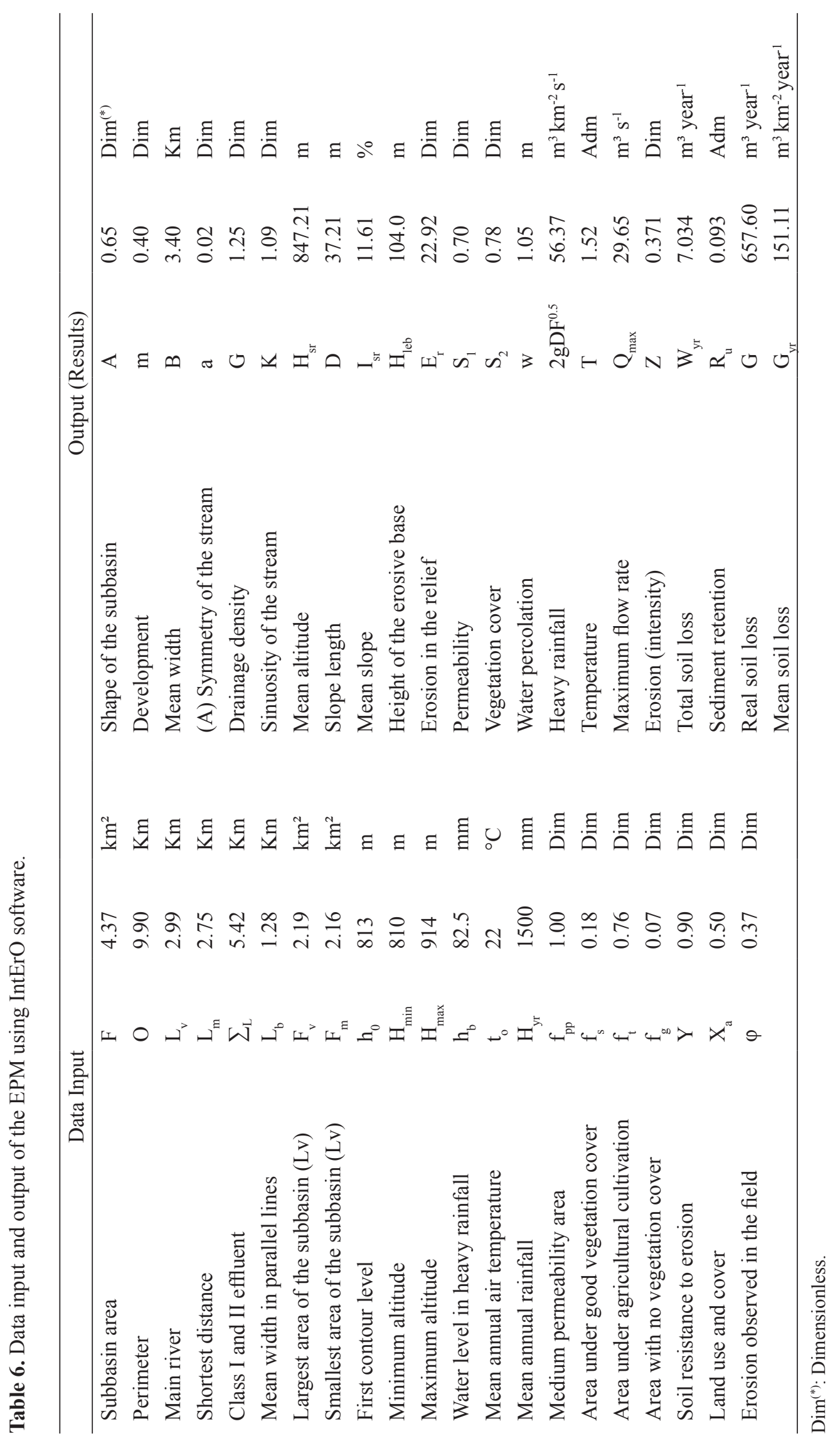


In the eucalyptus areas, the 301 soil loss points (pixels) considered (Figure 4B) had a weak and nonsignificant correlation with the slope in the EPM $(\mathrm{r}=0.12 ; \mathrm{p}=0.038)$ and in the RUSLE $(\mathrm{r}=0.14$; $\mathrm{p}=0.015)$. However, they showed a significant correlation between the two models $(r=0.78$; $p<$ 0.001 ), indicating similarities between the values in the parameters " $\mathrm{X}_{\mathrm{a}}$ " and " $\varphi$ " of the EPM and " $\mathrm{C}$ " and "P" of RUSLE.

In the access routes (Figure 4C), the 160 points considered did not show a correlation between the soil losses in the two models $(r=0.006 ; p=0.945)$ and with the slope. In the RUSLE, soil losses of 100 $\mathrm{Mg} \mathrm{ha}{ }^{-1}$ year $^{-1}$ were obtained, while in the EPM, soil losses of $8.5 \mathrm{Mg} \mathrm{ha}^{-1}$ year $^{-1}$ were obtained. The soil losses in these areas were considered statistically random in both models. However, the RUSLE model may overestimate the actual soil losses, while the EPM may underestimate these values. Therefore, because higher soil loss rates are observed in these areas in both models, these areas should be prioritized for adopting erosion mitigating practices.

In native forests (Figure 4D), 1,095 points were evaluated, and they presented a weak correlation $(\mathrm{r}=0.13 ; \mathrm{p}<0.001)$ between the models. In these areas, the correlation between the slopes and the soil losses in both models was not significant in the EPM $(r=0.35 ; p<0.001)$ and in the RUSLE ( $r=0.038 ; p=0.209)$ due to the concentration of native forests along the lowest slopes, which are in the permanent protection areas in the margins of the bodies of water. In the areas with corn and beans in succession (Figure 4E), 1,155 soil loss points were analyzed, and a significant correlation was observed between the models $(\mathrm{r}=0.44 ; \mathrm{p}<0.001)$, and no correlation was observed with the slope.

Figure 4. Scatterplot of soil losses based on the EPM and RUSLE models according to the following uses: coffee crops (A), eucalyptus (B), access routes (C), native forest (D) and corn and beans in succession (E).

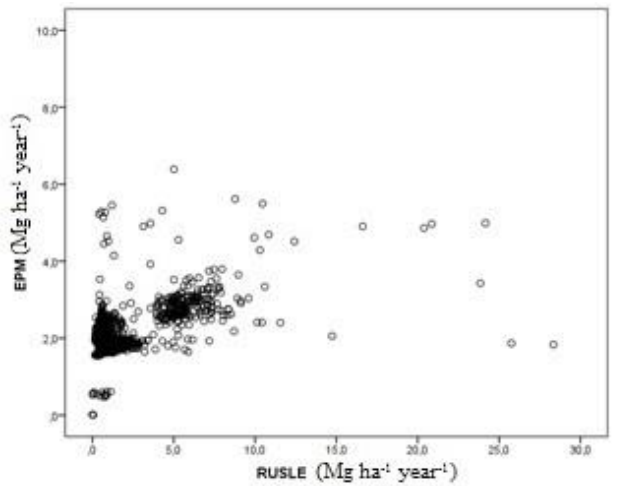

(A)

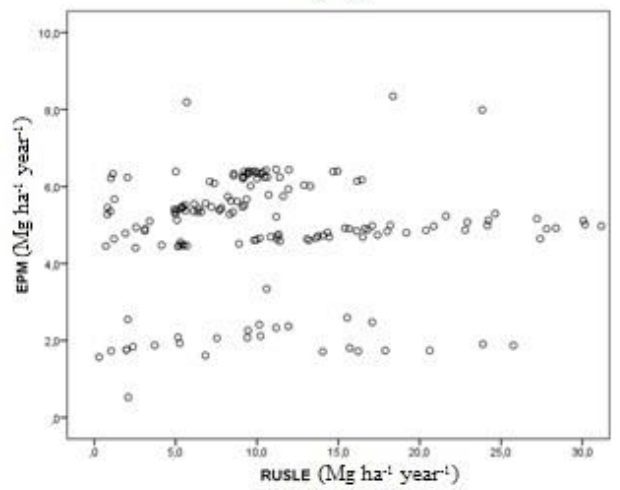

(C)

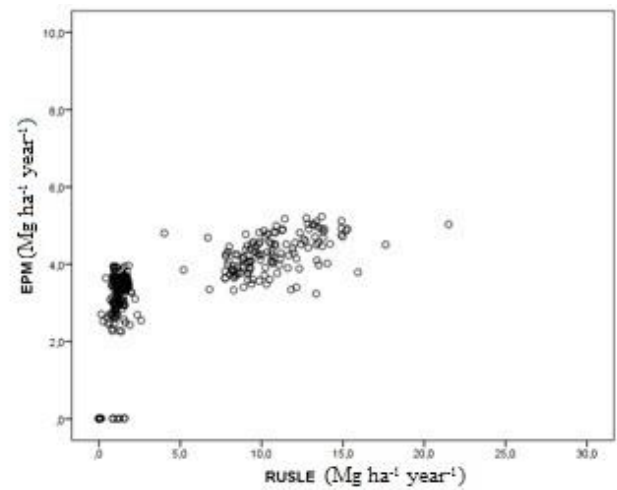

(B)

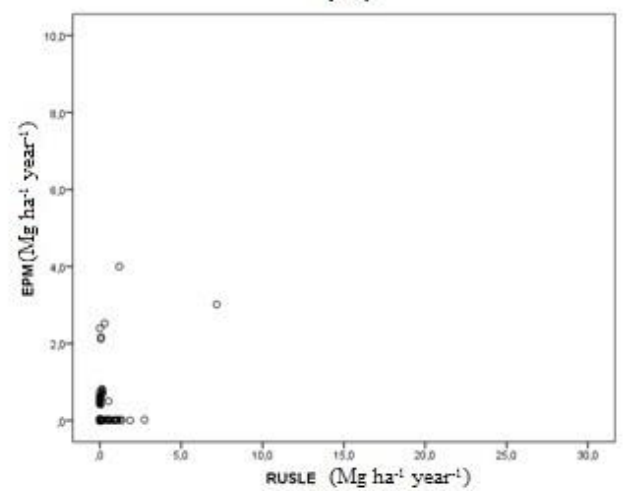

(D) 
continuation

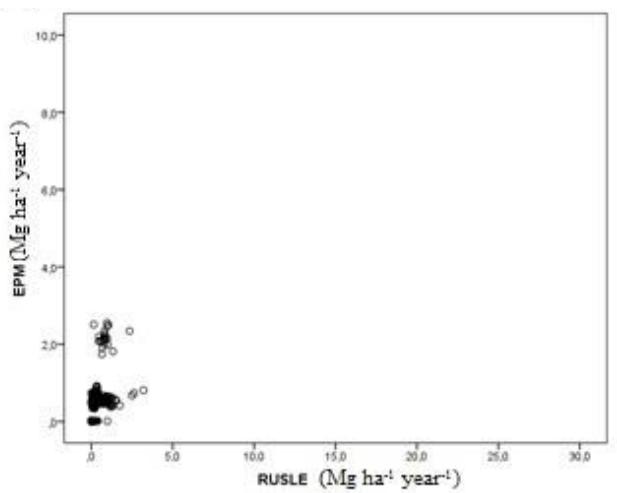

(E)

The correlations of the potential values of soil losses between the two models showed a similar pattern for the different land uses and management types despite the different orders of magnitude. The differences in losses may be due to the different methods adopted for obtaining the factors used in soil loss estimates. Thus, new studies should focus on performing comparisons and relative calibrations of the corresponding parameters in the two models. However, it should be noted that in average terms, the EPM presented the same trend as the RUSLE and can be used for global erosion estimates on river basin scales.

\section{Conclusions}

1. The mean soil loss ranged between 0.009 and $5.50 \mathrm{Mg} \mathrm{ha}^{-1}$ year $^{-1}$ in the EPM and between 0.04 and $18.64 \mathrm{Mg} \mathrm{ha}^{-1}$ year $^{-1}$ in the RUSLE model. The mean loss in coffee crops $(54.31 \%)$ was below the soil loss tolerance $\left(5.69 \mathrm{Mg} \mathrm{ha}^{-1}\right.$ year $\left.^{-1}\right)$ in both models. In the EPM and RUSLE models, only 1.5\% and $7.3 \%$ of the area showed potential soil losses above the soil loss tolerance limit, respectively.

2. In the EPM and RUSLE, the highest rates of soil loss occurred in eucalyptus areas and access routes due to the lack of conservation management practices. These areas should be prioritized for the mitigation of erosion rates as well as for the adoption of soil conservation and soil loss monitoring practices.
3. The estimation of potential soil losses and erosion intensity by the EPM supports the assessment of degradation risks of tropical soils, and it has the potential to represent an important tool for assessing the conditions of agricultural activities.

4. The EPM results should be considered environmental indicators since they require experimental validation to calibrate the coefficients assigned in the model.

\section{Acknowledgments}

The authors thank the Ipanema Agrícola S.A. (Ipanema Coffees) for logistical support and financing of the laboratory analyses; the Department of Soil Science of the Federal University of Lavras (UFLA) for the technical support and assistance in carrying out the soil analyses; the FAPEMIG, projects CAG-APQ 01053-15 and APQ 0080218; and the CNPq, projects $306511 / 2017-7$ and 202938/2018-2.

\section{References}

AGÊNCIA NACIONAL DE ÁGUAS - ANA. HidroWeb: Sistemas de Informações Hidrológicas - Séries Históricas. Brasília: ANA, 2016. Disponível em: <http://www.snirh. gov.br/hidroweb/2016>. Acesso em: 10 ago. 2016.

AQUINO, R. F.; SILVA, M. L. N.; FREITAS, D. A. F.; CURI, N.; MELLO, C. R.; AVANZI J. C. Spatial variability of the rainfall erosivity in Southern region of Minas Gerais State, Brazil. Ciência e Agrotecnologia, Lavras, v. 36, n. 5, p. 533-542, 2012. 
ARSHAD, M. A.; LOWERY, B.; GROSSMAN, B. Physical tests for monitoring soil quality. In: DORAN, J. W.; JONES, A. J. (Ed.). Methods for assessing soil quality. Madison: Soil Science Society of America, SSSA Special Publication, 1996. n. 49, p. 123-141.

AYER, J. E. B.; OLIVETTI, D.; MINCATO, R. L.; SILVA, M. L. N. Erosão hídrica em Latossolos Vermelhos Distróficos. Pesquisa Agropecuária Tropical, Goiania, v. 45, n. 2, p. 180-191, 2015.

BERTOL, I.; ALMEIDA, J. A. Tolerância de perda de solo por erosão para os principais solos do estado de Santa Catarina. Revista Brasileira de Ciência do Solo, Viçosa, MG, v. 24, n. 3, p. 657-668, maio 2000.

BERTOL, I.; SCHICK, J.; BATISTELA, O. Razão de perdas de solo e fator $\mathrm{C}$ para as culturas de soja e trigo em três sistemas de preparo em um Cambissolo Húmico alumínico. Revista Brasileira de Ciência do Solo, Viçosa, MG, v. 26, n. 2, p. 545-552, 2001.

BESKOW, S.; MELLO, C. R.; NORTON, L. D.; CURI, N.; VIOLA, M. R.; AVANZI, J. C. Soil erosion prediction in the Grande River Basin, Brazil using distributed modeling. Catena, Amsterdam, v. 79, p. 49-59, oct. 2009.

BLACK, C. A. Methods of soil analysis. Part. I: physical and mineralogical methods. $2^{\text {th }}$ ed. Madison: Soil Science Society of America, 1986. 1188 p.

BLAKE, G. R.; HARTGE, K. H. Bulk density. In: KLUTE, A. (Ed.). Methods of soil analysis. Part I. $2^{\text {th }}$ ed. Madison: American Society of Agronony, 1986. p. 363375.

BRADY, N. C.; WEIL, R. R. Elementos da natureza e propriedades dos solos. 3. ed. Porto Alegre: Bookman, 2013, 704 p.

CÂNDIDO, B. M.; SILVA, M. L. N.; CURI, N.; BATISTA, P. V. G. Erosão hídrica pós-plantio em florestas de eucalipto na Bacia do Rio Paraná, no Leste do Mato Grosso do Sul. Revista Brasileira de Ciência do Solo, Viçosa, MG, v. 38, n. 5, p. 1565-1575, 2014.

DANIELSON, R. E.; SUTHERLAND, P. L. Porosity. In: KLUTE, A. (Ed.). Methods of soil analysis. Part I. $2^{\text {th }}$ ed. Madison: American Society of Agronony, p. 443-461, 1986.

DE VENTE, J.; POESEN, J. Predicting soil erosion and sediment yield at the basin scale: scale issues and semiquantitative models. Earth-Science Reviews, Leuven, v. 71, n. 91, p. 95-125, feb. 2005.

DRAGICEVIC, N.; KARLEUSA, B.; OZANIC, N. A review of the Gavrilovic method (Erosion Potential Method) application. Gradevinar, v. 68, n. 9, p. 715-725, sep. 2016.
DYONISIO, H. A. F. Erosão hídrica: suscetibilidade do solo. Revista Eletrônica Thesis, São Paulo, ano VII, n. 13 , p. 15-25, abr. 2010.

EFTHIMIOU, N.; LYKOUDI, E.; PANAGOULIA, D.; KARAVITIS, C. Assessment of soil susceptibility to erosion using the EPM and RUSLE Models: the case of Venetikos River Catchment. Global NEST Journal, Athens, v. 18, n. 1, p. 164-179, 2016.

EMPRESA BRASILEIRA DE PESQUISA AGROPECUÁRIA - EMBRAPA. Sistema Brasileiro de Classificação de Solos. 4. ed. Brasília: EMBRAPA Solos, 2013. 376 p.

ENVIRONMENTAL SYSTEMS RESEARCH INSTITUTE - ESRI. Inc. ARCGIS Professional GIS for the desktop. Version 10.3. Software Redlands: Environmental Systems Research Institute, 2015.

FOOD AND AGRICULTURE ORGANIZATION OF THE UNITED NATIONS - FAO. World Reference Base for Soil Resources (WRB): update 2015 International soil classification system for naming soils and creating legends for soil maps. Rome: FAO, 2015. n. 106, 203 p.

GALINDO, I. C. L.; MARGOLIS, E. Tolerância de perdas por erosão para solos do estado de Pernambuco. Revista Brasileira de Ciência do Solo, Campinas, v. 13, n. 1, p. 95-100, 1989.

GAVRILOVIC, S. The torrential flows and erosion. (Torrents and erosion in Serbian). Belgrade: Gradevinsky calendar, $1976.311 \mathrm{p}$.

GAVRILOVIC, S. The use of empirical method (Erosion Potential Method) for calculating sediment production and transportation in unstudied or torrential streams. In: WHITE, W. R. (Ed.). International conference on river regime. Chichester: John Wiley \& Sons, Chichester, 1988. p. 411- 422 .

GLOBEVNIK, L.; HOLJEVIC, D.; PETKOVSEK, G.; RUBINIC, J. Applicability of the Gavrilovic method in erosion calculation using spatial data manipulation techniques. In: DE BOER, D.; FROEHLICH, W.; MIZUYAMA, T.; PIETRONIRO, A. (Ed.). Erosion prediction in ungauged basins: integrating methods and techniques. Wallingford: IAHS Publication, 2003. v. 279, p. 224-233.

GROHMANN, F. Distribuição do tamanho de poros em três tipos de solo do Estado de São Paulo. Bragantia, Campinas, v. 19, n. 21, p. 319-328, 1960.

INSTITUTO BRASILEIRO DE GEOGRAFIA E ESTATÍSTICA - IBGE. Carta Topográfica do Município de Alfenas (FOLHA SF 23-1-1-3). Rio de Janeiro: IBGE, 1970 . 
INSTITUTO BRASILEIRO DE GEOGRAFIA E ESTATÍSTICA - IBGE. Manual técnico de pedologia. 3. ed. Rio de Janeiro: IBGE, 2015. 430 p.

INSTITUTO NACIONAL DE METEOROLOGIA - INMET. Estações pluviométricas convencionais. Brasília: Ministério da Agricultura, Pecuária e Abastecimento (MAPA), 2016. Disponível em: <http:// www.inmet.gov.br/portal/index.php?r=estacoes/ estacoesConvencionais $>$. Acesso em: 07 jul. 2016.

MCBRATNEY, A. B. M.; SANTOS, L. M.; MINASNY, B. On digital soil mapping. Geoderma, Beijing, v. 117, n. 1, p. 3-52, 2003.

MINELLA, J. P. G.; MERTEN, G. H.; MAGNAGO, P. F. Análise qualitativa e quantitativa da histerese entre vazão e concentração de sedimentos durante eventos hidrológicos. Revista Brasileira de Engenharia Agrícola e Ambiental, Campina Grande, v. 15, n. 12, p. 1306-1313, 2011.

MITASOVA, H., Hofierka, J., Zlocha, M., Louis R. Iverson, L. R. Modelling topographic potential for erosion and deposition using GIS, International Journal of Geographical Information Systems, London, v. 10, n. 5, p. 629-641, 1996.

OLIVEIRA,A. H.; SILVA, M.A.; SILVA, M. L. N.; CURI, N.; KLINKE, G. N.; FREITAS, D. A. F. Development of topographic factor modeling for application in soil erosion models. In: SORIANO, M. C. H. Soil processes and current trends in quality assessment. Rijeka: InTech, 2013. n. 4, p. 111-138.

OLIVEIRA, F. G.; SERAPHIM, O. J.; BORJA, M. E. L. Estimativa de perdas de solo e do potencial natural de erosão da Bacia de Contribuição da Microcentral Hidrelétrica do Lageado, Botucatu-SP. Energia na Agricultura, Botucatu, v. 30, n. 3, p. 302-309, 2015.

OLIVETTI, D.; MINCATO, R. L.; AYER, J.E. B.; SILVA, M. L. N.; CURI, N. Spatial and temporal modeling of water erosion in dystrophic Red Latosol (Oxisol) used for farming and cattle raising activities in a subbasin in the South of Minas Gerais. Ciência e Agrotecnologia, Lavras, v. 39, n. 1, p. 58-67, 2015.

OLSZEVSKI, N.; FERNANDES FILHO, E. I.; COSTA, L. M.; SCHAEFER, C. E. G. R.; SOUZA, E.; COSTA, O. D. V. Morfologia e aspectos hidrológicos da Bacia Hidrográfica do Rio Preto, divisa dos Estados do Rio de Janeiro e de Minas Gerais. Revista Árvore, Viçosa, MG, v. 35 , n. 3, p. 485-492, 2011.

PANAGOS, P.; BORRELLI, P.; MEUSBURGER, K.; ALEWELL, C.; LUGATO, E.; MONTANARELLA, L. Estimating the soil erosion cover-management factor at the European Scale. Land Use Policy, Amsterdan, v. 48, p. 38-50, 2015.

PROCHNOW, D.; DECHEN, S. C. F.; MARIA, I. C. de; CASTRO, O. M. de; VIEIRA, S. R. Razão de perdas de terra e fator $\mathrm{C}$ da cultura do cafeeiro em cinco espaçamentos, em Pindorama (SP). Revista Brasileira de Ciência do Solo, Viçosa, v. 29, n. 1, p. 91-98, 2005.

PRUSKI, F. F. Conservação de solo e água: práticas mecânicas para o controle da erosão hídrica. Viçosa, MG: Ed. Viçosa, 2009. 240 p.

RENARD, K. G.; FOSTER, G. R.; WEESIES, G. A.; MCCOOL, D. K.; YODER, D. C. Predicting soil erosion by water: a guide to conservation planning with the Revised Universal Soil Loss Equation (RUSLE). Washington: United States Department of Agriculture, 1997. v. 703, 384 p.

SANTOS, L. N. S.; CECÍLIO, R. A.; ZANETTI, S. S. Aplicação do modelo HidroBacia na microbacia do Córrego Junqueira, Espírito Santo. Semina: Ciências Agrárias, Londrina, v. 34, n. 5, p. 2103-2116, 2013.

SANTOS, R. D. dos; SANTOS, H. G. dos; KER, J. C.; ANJOS, L. H. C. dos; SHIMIZU, S. H. Manual de descrição e coleta de solos no campo. 5. ed. Viçosa, MG: Sociedade Brasileira de Ciência do Solo (SBCS). EMBRAPA - Centro Nacional de Pesquisa de Solos (CNPS), 2015. $102 \mathrm{p}$.

SCHULTZ, N.; ANJOS, L. H. C. dos; PEREIRA, M. G.; DORTZBACH, D. O conhecimento dos solos. Viçosa, MG: Sociedade Brasileira de Ciências do Solo (SBCS), 2014. v. 39, 56 p. (Boletim Informativo, n. 3).

SILVA, B. P. C.; SILVA, M. L. N.; BATISTA, P. V. G.; PONTES, L. M.; ARAÚJO, E. F.; CURI, N. Perdas de solo e água em plantios de eucalipto e floresta nativa e determinação dos fatores da USLE em sub-bacia hidrográfica piloto no Rio Grande do Sul, Brasil. Ciência e Agrotecnologia, Lavras, v. 40, n. 4, p. 432-442, 2016.

SILVA, M. L. N.; CURI, N.; FERREIRA, M. M.; LIMA, J. M. de; FERREIRA, D. F. Proposição de modelos para estimativa da erodibilidade de Latossolos brasileiros. Pesquisa Agropecuária Brasileira, Brasília, v. 34, n. 12, p. 2287-2298, 1999.

SILVA, R. M.; CELSO, A. G. S.; SILVA, A. M. Predicting soil erosion and sediment yield in the Tapacurá catchment, Brazil. Journal of Urban and Environmental Engineering, João Pessoa, v. 8, n. 1, p. 75-82, 2014.

SOIL SURVEY DIVISION STAFF - SSDS. Soil survey manual. Soil Conservation Service. U.S. Department of Agriculture. Purdue: USDA, 1993. n. 18, 155 p. (Handbook). 
SPALEVIC, V. Impact of land use on runoff and soil erosion in Polimlje. 2011. Doctoral Thesis on Agriculture in the University of Belgrade, Serbia. $260 \mathrm{p}$.

SPAROVEK, G.; VAN LIER, Q. J.; DOURADO NETO, D. Computer assisted Köppen climate classification: a case study for Brazil. International Journal of Climatology, Hoboken, v. 27, n. 2, p. 257-266, 2007.

SPERANDIO,H.V.; CECÍCILO,R.A.;CAMPANHARO, W. A.; CARO, C. F. D.; HOLLANDA, M. P. Avaliação da erosão hídrica pela alteração na superfície do solo em diferentes coberturas vegetais de uma sub-bacia hidrográfica do Município de Alegre, ES. Semina: Ciências Agrárias, Londrina, v. 33, n. 4, p. 1411-1418, 2012.

STATISTICAL PACKAGE FOR THE SOCIAL SCIENCES AND INTERNATIONAL BUSINESS MACHINES - SPSS-IBM. IBM SPSS Modeler. Armonk, Nova Iorque: IBM, 2017. Avaliable at: $<$ htSLT://www. ibm.com/analytics/us/en/technology/spss/\#what-isspss $>$. Acessed at: 15 mar. 2017.

TANGESTANI, M. H. Comparison of EPM and PSIAC models in GIS for erosion and sediment yield assessment in a semi-arid environment: Afzar Catchment, Fars Province, Iran. Journal of Asian Earth Sciences, Hong Kong, v. 5, n. 27, p. 585-597, 2006.

TERRANOVA, O.; ANTRONICO, L.; COSCARELLI, R.; IAQUINTA, P. Soil erosion risk scenarios in the Mediterranean environment using RUSLE and GIS: an application model for Calabria, southern Italy. Geomorphology, Perth, v. 112, n. 4, p. 228-245, 2009.
UNIVERSIDADE FEDERAL DO RIO DE JANEIRO UFRJ; COMPANHIA DE PESQUISA DE RECURSOS MINERAIS - CPRM. Mapa Geológico da Folha Alfenas (SF-23-V-D-II). Escala 1:100.000. Rio de Janeiro: CPRM, 2010.

VILlELA, S. M.; MATTOS, A. Hidrologia aplicada. São Paulo: McGraw-Hill, 1975. 245 p.

VUJACIC, D.; SPALEVIC, V. Assessment of runoff and soil erosion in the Radulicka Rijeka Watershed, Polimlje, Montenegro. Agriculture \& Forestry, Podgorica, v. 62, n. 2, p. 283-292, 2016.

WISCHMEIER, W. H.; SMITH, D. D. Predicting rainfall erosion losses. A guide to conservation planning. Washington: USDA, 1978. 58 p.

YOUSEFI, S.; KIVARZ, N. M.; RAMEZANI, B.; RASOOLZADEH, N.; NADERI, N.; MIRZAEE, S. An estimation of sediment by using erosion potential method and geographic information systems in chamgardalan watershed: a case study of Ilam Province, Iran. Geodynamics Research International Bulletin - GRIB, Tehran, v. 2, n. 2, p. 1-5, 2014.

ZHANG, R. Determination of soil sorptivity and hydraulic conductivity from the disk infiltrometer. Soil Science Society of America Journal, Madison, v. 61, n. 4, p. 1024-1030, 1997.

ZORN, M.; KOMAC, B. Response of soil erosion to land use change with particular reference to the last 200 years (Julian Alps, Western Slovenia). Revista de Geomorfologie, Bucareste, v. 11, n. 1, p. 39-47, 2009. 
